\title{
Symposium
}

\section{Constitutional Change and the Politics of History}

\author{
William E. Forbath ${ }^{\dagger}$
}

Everyone knows that historians and legal scholars do history differently. Laura Kalman, a contributor to this Symposium, has put it nicely. Historians favor "context, change, and explanation"; legal scholars value "text, continuity and prescription." "The historians' role is to scold the law scholars for doing law-office history, for "getting it wrong," ironing out context and discontinuity to muster the past into present service. This Symposium, however, is a conversation between historians and a lawyerdoing-history that does not follow this familiar script. The lawyer still aims for prescription, but like the historians, his focus is change. Indeed, Bruce Ackerman aims to prescribe new rules and standards to govern big changes in the Constitution, and he claims to do so via history, by examining how big changes actually have unfolded and by teasing out their immanent patterns, rules, and grammar. ${ }^{2}$ Ackerman also is a champion of context. "We must," he repeatedly declares, "learn to see the Founders as they saw themselves." 3 So, more than usual, the parties to this interdisciplinary conversation about the Founding, Reconstruction and New Deal eras in American constitutional history are writing on the same page.

Not only are they life-long students of the periods Ackerman has dubbed "constitutional moments," but several of the distinguished historians and students of American political development gathered here resemble Ackerman in another way. Their work is attuned to the ways that the available narratives about the constitutional past have shaped the

$\dagger$ Angus G. Wynne, Sr. Professor of Civil Jurisprudence and Professor of History, The University of Texas at Austin.

1. LAURA KALMAN, THE STRANGe CAREER OF LEGAL LibERALISM 10 (1996).

2. See 2 BRUCE ACKERMAN, WE THE PEOPLE: TRANSFORMATIONS (1998).

3. 1 BRUCE ACKERMAN: WE THE PEOPLE: FOUNDATIONS 165 (1991). 
meanings Americans have been able to give their present and future. ${ }^{4}$ These commonalities do not erase the great differences between the lawyer and the historians; instead, they mean that the conversation and the differences unfold on a deeper plane. There are fascinating interpretive disagreements, as well as theoretical differences that range from the politics and morality of history to underlying conceptions of historical process. The conceptual and theoretical disagreements are often implicit, and this Introduction flags them. It also briefly sketches a rival narrative of constitutional moments that takes account of the historians' criticisms.

Bruce Ackerman has put the problem of change on the agenda of constitutional scholarship. How do we describe and justify large-scale, nonincremental changes in the United States Constitution? In We the People: Foundations, Ackerman indicted lawyers' "professional narrative" about these changes on two main counts. Their storyline is wildly untrue; and it falsely belittles the "constitutional creativity and achievements of ordinary citizens, continuing into the 20th century." $"$ The professional narrative, Ackerman observed, accounts for big changes either by shoehorning them into the procedures outlined in Article $\mathrm{V}$ of the Constitution, or by contending that big changes are really only "restorations" of the old order. Thus, first this narrative slights the fact that the Founding broke with legality by flouting the rules of amendment prescribed in the Articles of Confederation. Next, the professional narrative simply papers over and ignores the gulf between Article $\mathrm{V}$ procedures and the actual manner in which the Thirteenth and Fourteenth Amendments were enacted. Finally, it

4. For Joyce Appleby, this has provoked theoretical reflections on how historical narratives have figured historically in the ways people have thought and fought about ideas like liberty, equality, and citizenship, while for Laura Kalman it has inspired a lively intellectual history of the "historical turn" among liberal-minded constitutional scholars during the Rehnquist-era. See JOYCE APPLEBY ET AL., TELlING THE TRUTH ABOUT HistORY (1994); KALMAN, supra note 1. The same insight informs Sanford Levinson's work on the plurality of constitutional texts and meanings. See SANFORD LEvinson, CONSTITUTIONAL FaITH (1988); J.M. Balkin \& Sanford Levinson, The Canons of Constitutional Law, 111 HARV. L. REV. 963 (1998).

Eric Foner and Rogers Smith have produced new and heterodox grand narratives, aiming, like Ackerman's, to challenge and deepen our constitutional/historical self-understandings. Like We the People, their narratives attend to "real-world processes," 2 ACKERMAN, supra note 2, at 112, involving social movements, political parties, lawmakers and Presidents as well as courts in conflicts over national identity, citizenship rights, and the powers and duties of government. See ERIC FONER, RECONSTRUCTION: AMERICA'S UNFINISHED REVOLUTION, 1863-1877 (1988); ERIC FONER, THE STORY OF AMERICAN FREEDOM (1998); ROGERS M. SMITH, CIVIC IDEALS: CONFLICTING VISIONS OF CITIZENSHIP IN U.S. HISTORY (1997). In the same vein is WILLIAM E. FORBATH, LAW AND THE SHAPING OF THE AMERICAN LABOR MOVEMENT (1991).

In several celebrated books and essays, Walter Dean Burnham has produced an enormously important account about the role of party-formation and "critical elections" in American political development; his influence on Ackerman's work is plain. See THE AMERICAN PARTY SYSTEMS: STAGES OF POLITICAL DEVELOPMENT (William Nesbet Chambers \& Walter Dean Burnham eds., 2d ed. 1967); WALTER DEAN BURNHAM, CRITICAL ElECTIONS AND THE MAINSPRINGS OF AMERICAN POLITICS (1970).

5. 1 ACKERMAN, supra note 3 , at $42-44$. 
insists that the vast changes in federal-state relations heralded by the New Deal Constitution marked no rupture with the past, but either a restoration of John Marshall's Constitution or a faithful judicial translation thereof.

Perhaps, as Sanford Levinson suggests, no one but professional lawyers and legal academics could take this "absurdly naive" narrative seriously. ${ }^{6}$ Only they have a professional investment in the idea that great ruptures between one constitutional regime and the next can be recounted in a storyline that builds a legally legitimate bridge between them. ${ }^{7}$ For political scientists and historians, it comes as no shock that moments of great constitutional change overflowed legal processes of legitimation. ${ }^{8}$ Indeed, many lawyers will concur and conclude with Stephen Griffin, that in each of Ackerman's "moments," the key actors found the law inadequate to the crisis at hand. They did not resort to naked force to move the nation from one constitutional regime to the next. Rather, they found compelling moral and political grounds beyond law, appealed for support, and prevailed. ${ }^{9}$

Ackerman is a traditional legalist in finding such "beyond law" talk shallow and dangerous. However, he is a legalist prepared to confront the genuinely problematic legality of the Reconstruction and New Deal transformations. In We the People: Foundations, Ackerman claimed the discovery of an elaborate and evolving pattern of higher lawmaking norms, a common law of higher lawmaking, that has governed constitutional transformations outside Article V-but not beyond law. With this discovery he claimed to redeem not only the view that our great constitutional transformations were lawful ones, but also the "possibility of popular sovereignty" as the real engine of constitutional change, and the "possibility of interpretation" as a properly backward-looking, conservative enterprise wherein the judiciary "preserves" the higher law wrought by "We the People" in our rare moments of constitutional awakening against the incursions of "ordinary politics." 10

We the People: Transformations aims to provide the historical evidence to support this claim. Judicial interpretation and rules of recognition for constitutional courts to apply are not the subject of this volume; rather it is "how American institutions have in fact operated to organize popular debate and decision during our most creative periods of constitutional politics."11

6. See Sanford Levinson, Transitions, 108 YALE L.J. 2215, 2223 (1999).

7. See, e.g., Laurence H. Tribe, Taking Text and Structure Seriously: Reflections on FreeForm Method in Constitutional Interpretation, 108 HARV. L. REV. 1223 (1995) (defending the received professional narrative against Ackerman and others).

8. See Levinson, supra note 6, at 109; Jack N. Rakove, The Super-Legality of the Constitution, or, a Federalist Critique of Bruce Ackerman's Neo-Federalism, 108 YALE L.J. 1931, 1937 (1999).

9. Stephen M. Griffin, Constitutional Theory Transformed, 108 YALE L.J. 2115, 2148-51 (1999).

10. 1 ACKERMAN, supra note 3 , at 131-62.

11. 2 ACKERMAN, supra note 2 , at 6 . 
This helps make the second volume a more congenial one for historians. It offers rich, insightful accounts of these moments of high politics, when not only fundamental constitutional values and doctrines were contested, but basic institutional arrangements (the boundaries between state and civil society, government and market, federal and state authority) and basic questions of national identity (who belongs to "We the People," and what rights and duties attach to membership in the national community) were up for grabs. During such constitutive moments, social movements, ordinary voters, reformers as well as politicians, parties, lawmakers and Presidents all occupy the constitutional-political stage. Ackerman insists he has taken the measure of these complex and seemingly unruly processes of change and cashed out a set of formal rules and principles-a grammar of legitimation, more in the manner of structuralist anthropology than legal theory-that has enabled successful "revolutionary reformers" 12 to earn the authority to speak for "the People" during these moments and to translate their constitutional-political visions into law. His may be the most elaborate and ambitious process-based constitutional theory.

Thus, Ackerman portrays the Federalists acting extralegally, using inherited institutions, like the convention, in new ways, to earn such authority. He distinguishes five stages of this process of higher lawmaking: "signalling," "proposing," "triggering," "ratifying," and "consolidating," 13 and argues that this constitutional-political process, not compliance with prescribed rules for amendment, accounts for the legitimacy of the constitutional change brought about by the Founding. $\mathrm{He}$ then applies the precedent of the Founding to Reconstruction, ${ }^{14}$ first highlighting how the "Republicans played fast and loose with the Federalists' text [Article V]," then suggesting why they nevertheless may have "remained faithful to the precedent established by the Founding practice." 15 The "stages" supplied the precedent. Reconstruction, however, witnessed a nationalizing shift away from the Founders' balance of state and federal higher lawmaking arenas, and toward reliance on: (a) first presidential and later congressional leadership; (b) the dynamics of interbranch conflict set in play by the separation of powers; and finally (c) popular mandates secured through national elections. ${ }^{16}$

The stages exfoliate. "Ratification" has four phases of its own, which reflect the intricate interbranch clashes over Reconstruction policy. Lincoln and then Johnson put extraordinary pressures on the South to ratify the Thirteenth Amendment, but with the Fourteenth Amendment, Johnson

12. 2 id. at 13.

13. See, e.g., 2 id. at 32-68 (applying the five-stage model to the Founding).

14. See 2 id. at 99-252.

15. 2 id. at 100 .

16. See 2 id. at 236-51. 
stopped in his tracks. This prompted the Republicans on Capitol Hill to transform the regular election of 1866 into "one of the great higher lawmaking events of American history," going to the people with the Fourteenth Amendment as their platform and winning a mandate for constitutional reform. Johnson, however, denied the mandate and led ten Southern state governments to exercise the veto seemingly offered by Article V. The Republican Congress responded, in turn, by destroying those governments and demanding ratification in exchange for recognizing reconstructed governments in the South. When Johnson sought to stymie this plan, Congress impeached him. When Johnson backed down, he accepted the Republicans' claim to speak for the "People" in their newfound constitutional vision, and thereby set the precedent for that later "switch in time" on the part of the Supreme Court in 1937. Generalizing the pattern, Ackerman sums up the process "in terms of a simple schema: "Constitutional Impasse... Electoral 'Mandate'... Challenge to Dissenting Institutions ... the 'Switch in Time."' 17

It is not hard to see how this "ratifying" schema applies to New Deal history. Roosevelt's first term culminated in a constitutional impasse between the branches similar to that of 1866 . Once again, the separation of powers and interbranch conflict created the arena for constitutional debate, enabling the conservative branch to raise basic questions of legitimacy and to challenge the reformers to go to the People if they hoped for ultimate success. Then, when the New Dealers won crushing victories in the presidential and congressional elections of 1936, they claimed a mandate from the People in support of their constitutional vision.

Reconstruction and New Deal political history are not uncharted terrains. Yet Ackerman's distinct angle of vision, his single-minded focus on the processes of conflict, rather than on the substantive disputes about Reconstruction or New Deal policies, reveals a new wealth of detail, confirming his bold claim that the parties to these conflicts thought and spoke in self-conscious and sophisticated constitutional terms as they fought over the rules of engagement and the processes of change and resistance to change.

How, then, does Ackerman's account of these three moments fare in the historians' estimation? There are, as I have noted, fascinating disputes over the meaning and significance of particular texts and events. ${ }^{18}$ But is Ackerman right that the historians' criticisms "do not affect [his] central

17. Bruce Ackerman, Higher Lawmaking, in RESPONDING TO IMPERFECTION: THEORY AND PRACTICE OF CONSTTTUTIONAL AMENDMENT 63, 76-79 (Sanford Levinson ed., 1995).

18. See, e.g., Bruce Ackerman, Revolution on a Human Scale, 108 YALE L.J. 2279, 2295 n.22 (1999); Rakove, supra, note 8, at 1937-46, 1953-25 (debating the extent of the Founding's "illegality," and Madison's views on the appropriate role of popular participation in constitutional change). 
arguments?" 19 First, we should be clear that the historians simply do not address whether Ackerman's common law of higher lawmaking is a serviceable tool for courts to determine the bona fides of alleged non-Article $\mathrm{V}$ amendments, nor what kind of guidance, if any, courts, lawmakers, or citizens, finding themselves in the thick of constitutional politics, can derive from these ex post rules of recognition. They ask whether Ackerman's narrative and the patterns he highlights capture the "actualities" of constitutional change. Here, Ackerman is right that the historians' criticisms leave most of his descriptive account of the three moments standing-and many facets of it rightly earn their admiration. Ackerman is right too that a good deal of criticism points toward "gaps," ${ }^{20}$ but to my mind not all these "gaps" are empirical holes that can simply be filled without affecting the contours and premises of the project.

Some recurrent criticisms run deeper. There are shared misgivings about the triumphalist, Whiggish arc of Ackerman's moments. He neglects the contradictory character of his three moments-how profoundly each of them was shaped by its antagonists as well as its proponents, and how much of old-and less democratic-eonstitutional orders persisted in and prevailed over new ones. Ackerman also ignores the possibility of great constitutional changes that have followed neither Article $\mathrm{V}$ nor his legitimating model of higher-lawmaking. Foner and Burnham both highlight how the institutional and constitutional order of the late nineteenth- and early twentieth-century republic was twice transformed, first by Reconstruction and, then again, in the 1890s, by Reconstruction's foes and the larger "system of 1896," which legitimated Jim Crow and wove segregation and mass disenfranchisement into the constitutional fabric of the middle republic. Foner suggests that this dark fin-de-siècle moment of change received a kind of popular validation; ${ }^{21}$ Burnham implies that some of its central elements were imposed largely through force and fraud. ${ }^{22}$ Either way, this dark moment must change Ackerman's Whiggish narrative and the meanings and method it imparts to the present.

19. Ackerman, supra note 18 , at 114 .

20. Id.

21. See Eric Foner, The Strange Career of the Reconstruction Amendments, 108 YALE L.J. 2003, 2007-09 (1999).

22. See Walter Dean Burnham, Constitutional Moments and Punctuated Equilibria: A Political Scientist Confronts Bruce Ackerman's We the People, 108 YALE. L.J. 101, 2265 (1999). Burnham also points out the national institution "that led the way" for the "forces demanding change" during this "counter-revolutionary" moment was none other than the Supreme Court-a "pro-active" role for the judiciary that does not fit within Ackerman's scheme. Id. at 2269. Some have argued that the "activist" character of the 1890s-1900s Fuller Court provided a kind of institutional precedent for the Warren Court. Bumham does not take up this comparison, but he does ask whether the Warren Court's constitutional creativity "ever engaged any part of Ackerman's model." By Burnham's lights, the Warren "Court's higher lawmaking in and even after the Warren period developed in a vacuum so far as Ackerman's model is concemed." Id. at $2270-71$. 
The historians' insights complicate Ackerman's storyline in another way, by suggesting that U.S. history has been punctuated by many more moments of constitutive change than three. The Jeffersonian and Jacksonian elections and Presidencies, the rise of American imperialism at the turn of the twentieth century, the Progressive era, and even the civil rights movement of mid-century all emerge from these pages as candidates. Ackerman's own most recent writing notes that movements for fundamental reform-attended by popular mobilization around constitutive issues of national identity, popular sovereignty, and the powers and duties of government-brought forth new parties, pivotal elections, major institutional changes and doctrinal innovations in each generation of the nineteenth century. ${ }^{23}$ Thus Ackerman now seems to agree that even if his original three moments involved more sweeping changes, the differences between them and these others are not so great as to warrant the simple division of American historical time into three long periods of "normal politics" and three bursts of "constitutional politics" and "higher lawmaking." Taken together, these revisions imply a somewhat different narrative of constitutional development-more constantly changing, more tenaciously remaining the same, involving force-and-fraud-ridden changes as well as more or less democratic ones, and arrayed into many overlapping periods of ordinary and constitutional politics and lawmaking.

A final recurrent criticism runs to process and substance. How far can Ackerman bracket the substance of constitutional change and still render a persuasive account of the legitimating process? Smith and Foner both insist that one cannot understand the legitimation of Reconstruction apart from its moral and political content. ${ }^{24}$ Burnham and Les Benedict suggest a contrary possibility: that the popular will of white voters who endorsed the Fourteenth Amendment was overwhelmingly about punishing the South and not, as Ackerman claims, about forging a new non-racial understanding of national citizenship. ${ }^{25}$

Ackerman asserts rather than demonstrates an equivalence between the outlooks of reform elites and those of popular movements. The latter are the seedbed of new constitutional visions in Ackerman's theory, yet we never glimpse them or their visions in his narratives. To put it harshly, for Ackerman, the popular will was whatever elites said it was, ${ }^{26}$ and this

23. See Bruce Ackerman, The Broken Engine of Progressive Politics, AM. PROSPECT, MayJune 1998.

24. See Rogers Smith, Legitimating Reconstruction: The Limits of Legalism, 108 YALE L.J. 2039, 2043(1999); Foner, supra note 21, at 2006-07

25. See Burnham, supra note 22, at 2269-67; Michael Les Benedict, Constitutional History and Constitutional Theory: Reflections on Ackerman, Reconstruction, and the Transformation of the American Constitution, 108 YALE L.J. 2237, 2253 (1999).

26. Thus, in his most recent exposition, Ackerman writes that FDR spoke "directly for the leading movements of his time: the farmers, industrial workers, and liberal intelligentsia and 
equation helps underpin the claim that popular deliberation and decisionmaking are the heart of the Ackermanian higher-lawmaking process. In a given "moment," the equation may be true, but it cannot be assumed. The election returns are no substitute for examining how popular ideas and aspirations are tallied and translated or suppressed and erased in relations among social movements, political parties, lawmakers, and Presidents.

Could a narrative of constitutional moments absorb these criticisms? Would a more deeply historical account forsake Ackerman's hermeneutical enterprise-earrying on a conversation between generations about the contemporary constitutional meaning of past acts and commitments? Would it leave intact his claim to a purely process-based theory of legitimation? ${ }^{27}$

Ackerman, as the historians suggest, ignores how deeply the outcome of Reconstruction was shaped by Reconstruction's foes. Two waves of terror and disenfranchisement tell the familiar story. First the Southern Redeemers negotiated a modus vivendi with Northern business elites and their representatives in the Republican party, while at the same time, they smashed the Southern Republican party and state governments. Then at century's end, a second reign of terror and disenfranchising measures blotted out the remnants of Populism and secured a closed one-party system. ${ }^{28}$ This New South and its racial apartheid won a special constitutional status, becoming a distinct society within the Union's new constitutional order. ${ }^{29}$ Republicans as well as Democrats, courts, Congresses, and Presidents alike in large measure condoned this regime and participated in the weaving of Jim Crow, lynch law, and mass disenfranchisement into the constitutional fabric of the "middle republic." 30 The courts' bad faith-shared by the other branches-led to a fatal anomaly in the constitutional revolution of the New Deal-era, a reactionary core at the heart of New Deal liberalism.

professions." Bruce Ackerman, The Broken Engine of Progressive Politics, THE AM. PROSPECT, May-June 1998, at 34-40.

27. What follows draws on William E. Forbath, Caste, Class, and Equal Citizenship, 98 MICH. L. REV. (forthcoming Oct. 1999). Since Ackerman and others discuss that work, portions of which I presented at the Symposium on September 25, 1998, it seems useful very briefly to distill those parts here.

28. See DeWEy W. GRANTHAM, THE LIFE AND DEATH OF THE SOLID SOUTH: A POLITICAL HISTORY 26 (1988); see also J. MORGAN KOUSSER, THE SHAPING OF SOUTHERN POLITICS: SuFFRAGE RESTRICTIONS AND THE ESTABLISHMENT OF THE ONE-PARTY SOUTH 1880-1910 (1974) (describing the origins of the "solid South" and its one-party political system).

29. However, as Dean Burnham and others have suggested, Southern disenfranchisement bore a close resemblance to the "Progressive" measures that disenfranchised masses of mostly new immigrant urban workers in the North. See BURNHAM, supra note 4, at 78.

30. See, e.g., Williams v. Mississippi, 170 U.S. 213 (1898); Plessy v. Ferguson, 163 U.S. 537 (1896); The Civil Rights Cases, 109 U.S. 3 (1883); United States v. Harris, 106 U.S. 629 (1882); United States v. Cruikshank, 92 U.S. 542 (1875). A classic account of the Court's role is found in C. VANN WOODWARD, THE STRANGE CAREER OF JIM CROW 70-72 (2d ed. 1966). 
The reactionary core was the Solid South, and its role in the New Deal points to a problem in Ackerman's account of that "moment." Ackerman defines constitutional moments as occasions for revising fundamental commitments and redefining the rights of citizenship. ${ }^{31}$ How, then, did the New Deal moment redefine national citizenship? The New Deal, Ackerman writes, legitimated the national welfare state, but did it enact a non-Article $\mathrm{V}$ amendment guaranteeing a right to welfare? The Court may not be interested, but the conscientious legislator and citizen might like to know. ${ }^{32}$ Ackerman dodges the question. Nowhere in his detailed account of the constitutional politics of the New Deal moment does he explain how, if at all, citizenship rights were revised.

Precedent, we have seen, is Ackerman's method. To understand the New Deal moment, look to Reconstruction. When the Reconstruction Republicans enlarged the powers of Congress, they did so in the name of a new and enlarged conception of national citizenship. Sixty years later, New Dealers did the same. The constitutional choices they laid out during and after the 1936 elections were not only about national lawmakers' authority to regulate the economy. They also involved recognition of new rights and new rights-bearers. As with Reconstruction, the new, contended-for rights promised to supplant a body of law and custom that had codified an outcast, second-class status-in the first case the Black Codes, and in the second, the caste-ridden common law of employment and the status of millions of workers as "industrial serfs" or unemployed "outcasts." 33 Seeking a mandate for a great expansion of national power, it is no wonder New Dealers tied that expansion to popularly conceived precommitments in the form of social and economic rights. Yet for all his work with the texts, Ackerman offers a truncated picture of this phase of "ratification." $\mathrm{He}$ nowhere even mentions the principles or contours of this new conception of citizenship.

There is a reason for this studied silence, I think, that will return us to Reconstruction and to Jim Crow. First, however, let me describe the figure of citizenship that is missing in Ackerman's story but looms large in the texts he would have us consult. At its center was a right to decent work and a decent livelihood-a right to social provision and to a measure of economic independence and democracy. Its proximate sources were the era's social movements, like the industrial union movement, and the progressive reformers and policy mavens who formed the left wing of the New Deal coalition. As FDR and New Dealers in Congress sought to enlist and harness these movements and reformers, they adopted their rights

31. See 2 ACKERMAN, supra note 2, at 6-8; Ackerman, supra note 17, at 76.

32. See Paul Brest, The Conscientious Legislator's Guide to Constitutional Interpretation, 27 STAN. L. REV. 585 (1975).

33. See Forbath, supra note 27. 
rhetoric. ${ }^{34}$ Roosevelt spoke about these new rights and governmental duties under the rubric of a "general welfare Constitution," but he embraced a conception of welfare very different from ours. The "general welfare Constitution," like FDR's later "second Bill of Rights," encompassed social insurance and social provision broadly conceived, and above all it enshrined the "paramount right to work," or what New Dealers frequently called "employment assurance." 35

Where did this robust conception of citizenship originate, and how did it acquire any claim to constitutional moorings? That is a long and intricate story, which I tell elsewhere. ${ }^{36}$ Very schematically, what many of its architects called "social citizenship" emerged from a reform tradition that melded constitutional and political economic discourse and linked New Dealers to Progressives, Populists, and Radical Republicans. We have come to assume that movements like Populism and Progressivism were at one with Justice Holmes's insistence that constitutional discourse largely ought to be divorced from political economy. That was not so. Instead, they sought to replace the courts with elected lawmakers in the role of the nation's "authoritative" political economists. ${ }^{37}$ Holmes held that the Constitution allowed redistributive reforms; they claimed that it required them, or that it ought to.

The social citizenship tradition provided FDR and the New Dealers not only with rights rhetorics, but constitutional narratives, modes of interpretation, and ideas about the allocation of interpretive authority that supported their constitutional revolution. In his 1934 address to Congress announcing the formation of the Committee on Economic Security, FDR lectured the lawmakers and the nation about interpreting today the "old and sacred possessive" common-law rights of property and labor that the old Constitution enshrined. ${ }^{38}$ In pre-industrial America, these common-law rights had rich significance for the average citizen's freedom; now, only the recognition of new governmental responsibilities and new rights would enable "a recovery" of the old rights" once robust social meaning. ${ }^{39}$ This marked the first of FDR's increasingly pointed uses of the reformers' hermeneutics-the argument of changing conditions imperiling old

34. Id. Famously "pragmatic" and frequently cautious in his policy outlook, FDR often embraced only to abandon many of the specific programs of these movements. He proved constant, however, in his adoption of their rights rhetoric and language of citizenship and their constitutional outlook.

35. Id.

36. Id. (1924).

37. JOHN COMMONS, LEGAL Foundations OF CAPITALISM 7 (University of Wis. Press 1957)

38. Franklin Delano Roosevelt, Message to the Congress Reviewing the Objectives and Accomplishments of the Administration (June 8, 1934), in 3 PUB. PAPERS 291-92.

39. Id. at 292. 
principles and new interpretations, new rights, and new institutional arrangements restoring them.

By the later New Deal, social rights had found a secure place not only in reform rhetoric but in the discourse of the legal establishment. Thus, an American Law Institute drafting committee concluded that "the place of social and economic rights in any modern declaration of the rights of man had already been decided." ${ }^{40}$ In particular, no "modern understanding of a bill of rights" could omit the right to work, and the ALI committee anticipated Ackerman's idea of "framework statutes" supplementing formal constitutional provisions in expressing a "modern understanding" of the Bill of Rights. ${ }^{41}$

Some contemporary constitutional liberals like Cass Sunstein confidently rely on FDR's "second Bill of Rights" to clinch the argument that the New Deal Constitution enacted a constitutional right to minimum welfare entitlements. ${ }^{42}$ By contrast Ackerman, despite his characterization of constitutional moments as occasions for considered popular judgments on "the rights of citizens and the permanent interests of the community," 43 remains silent, as we have seen, and seemingly unsure about how, if at all, the New Deal Constitution redefined citizenship rights. And his uncertainty is justified. There is a gulf between the robust, encompassing rights talk of FDR's 1936 campaign and his "second Bill of Rights" and the far more partial patchwork of entitlements that comprised the New Deal's actial institutional legacy, a gap between the "mandate" and the outcome of the

40. John R. Ellingston, The Right To Work in Full Employment Act of 1945: Hearings Before a Subcomm. of the Sen. Comm. on Banking \& Currency on S. 380, 79th Cong. 1248-49 (1945).

41. As FDR sought enactment of expanded social insurance and an unequivocal federal commitment to full employment, in 1944 the American Law Institute (ALI) appointed a committee of legal luminaries to draft a "Statement of Essential Human Rights." The staff of the Senate committee holding hearings on FDR's 1945 "Full Employment Bill" asked the members of the ALI group to prepare "an analysis of the legal and philosophical considerations that led to the inclusion of the right to work" in the ALI Statement.

The ALI draftsmen set out to defend social rights "in the light of traditional [legal] habits of thought." Id. at 1254. To those who insisted on "looking upon rights as negative," the ALI draftsmen replied with arguments that continue to run through contemporary debates over positive versus negative rights. They tracked the Realist contention that, "as a theoretical matter," a recasting of the background rules of property and contract could readily render the positive right to work into a negative liberty, id.; likewise, they pointed out that several of the rights in the Bill of Rights "actually require government to take very positive action indeed... [entailing] all the involved and expensive machinery for the administration of civil and criminal justice.... In terms of mechanism and trained personnel, a system of social insurance is child's play in comparison with the system that gives effect to due process of law." Id. at 1255.

To the reproach that the right to work did not lend itself to judicial enforcement, they responded first that "legal imagination could develop new procedures" and second that, in any case, judicial administrability was not the right test of a right: "A Bill of Rights is more than a consolidation of the fractions of freedom already gained.... It is a directive to the whole society and a guide to legislatures and executives in the framing of laws and regulations that will gradually make the rights effective." Id. at 1258.

42. See Cass R. Sunstein, The Partial Constitution 138-39 (1993).

43. I ACKERMAN, supra note 3, at 240, 272-74. 
New Deal "moment," for which Ackerman's constitutional narrative provides no explanation. But an explanation is at hand, if one takes a more sober and historical look at our constitutional moments and the reversals and contradictions bound up with them.

Between the New Deal's popular constitutional "mandate" and its enactment fell the shadow of Jim Crow and the betrayal of Reconstruction. Bills instituting universal social citizenship enjoyed widespread support from Northern Democrats and had powerful champions in successive New Deal administrations and Congresses. They enjoyed broad but bootless support from disenfranchised Southern blacks and poor whites as well, but the poll tax, the literacy test, and other measures and forms of intimidation blocked them from voting. Instead, Southern Dixiecrats held the balance of power in Congress, and by dint of their numbers, seniority, and control of key committees, they thwarted these social citizenship measures. Over and against bills proposing universal coverage and national standards for social insurance programs, they insisted on decentralized administration and standard setting and demanded that key bills exclude the main categories of Southern labor. By allying with Northern Republicans, or by threatening to do so, the Solid South stripped all the main pieces of New Deal legislation of any design or provision that threatened the separate Southern labor market and its distinctive melding of class and caste relations, its racial segmentation and its low wages. ${ }^{44}$

By the 1940s, when measures like the Full Employment Bill appeared on Congress's docket, the Dixiecrats were in open revolt. Allied with Northern Republicans, they took the lead in defeating or dismantling the laws, agencies, and innovations that might have sustained the public rhetoric and generated the new institutional capacities and commitments embodied in the "all-important right to work," in the "right to useful, remunerative, regular ... employment," ${ }^{45}$ and "to education for work, for citizenship," 46 and ample opportunities for "training and retraining." 47

By the early 1940s, many New Dealers agreed that the future of New Deal reform depended on confronting Jim Crow. These years saw an outpouring of money and organizers by the $\mathrm{ClO}$ to produce an extraordinary

44. See Forbath, supra note 27 (manuscript at 97-101).

45. Full Employment Act of 1945: Hearings Before a Subcommittee of the Committee on Banking and Currency on S. 380, 79th Cong., 1st Sess. 2, 6 (1945).

46. United States Nat'l Resources Planning Bd., National Resources Development Report for 1943, 78th Cong., 1st Sess., 1943 Doc. No. 128, Part 1, Post War Plan and Program 3 (1943).

47. United States Nat'l Resources Planning Bd., Security, Work, and Relief Policies, Report of the Committee on Long-Range Work and Relief Policies 508. On the Dixiecrats' role in these defeats and dismantlings, see STEPHEN KEMP BAILEY, CONGRESS MAKES a LAW: THE STORY BEHIND THE EMPLOYMENT ACT OF 1946 (1950); MARION CLAWSON, NEW DEAL PLANNING: THE National Resources PlanNing Board 283-321 (1981); PHillip Harvey, Securing THE RIGHT TO EMPLOYMENT: SOCIAL WELFARE POLICY AND THE UNEMPLOYED IN THE UNITED STATES (1989); and MARGARET WEIR, POLITICS AND JOBS 132-79 (1992). 
voter registration drive in the South. In a few Southern states like Alabama and Georgia, the number of black and poor white voters increased severalfold. At a rally in Birmingham, one black leader recalled, "those 'first bright days of Reconstruction [when] the legislatures controlled by the newly freed slaves and the emancipated poor whites gave to our region its first democratic governments.' It was time, he said, for 'history to repeat itself." ${ }^{48}$ But that was not to be, not in time to complete the New Deal's unfinished reforms or enact the "Second Bill of Rights." The fraud, intimidation and violence that greeted the fragile Southern movement to revive the democratic promise of Reconstruction confirmed once more how such a regional movement ultimately depended on a national commitment to decisive action based on a broad interpretation of constitutionally protected civil and political rights. Presented with such a federal commitment in the late 1930s or early 1940s, perhaps a majority of hard-hit white Southerners would have proved willing to forsake old political identities rooted in states' rights and white supremacy, and wager once more on the promised boon of social citizenship wedded to racial justice. But states' rights and white supremacy remained too deeply etched in the national government and party system from which such a commitment would have had to emerge.

White America's and the federal government's abandonment of Reconstruction did more than deprive black Americans of civil and political rights for almost another century. By allowing the emergence and consolidation of the Solid South, this same constitutional bad faith also operated in the New Deal-era to prevent all Americans from securing the boon of social citizenship. Waged to secure those social and economic rights, the New Deal constitutional revolution was left incomplete because of white America's betrayal of an earlier revolution and its promise of equal citizenship for blacks. ${ }^{49}$

From the perspective of this history, the New Deal constitutional legacy that is under attack today-the "transformative opinions" or amendmentanalogues Ackerman seeks to defend from an unwarranted demise-is a marred one. We have enshrined the vast expansion of national governmental power, but not the purpose for which it was expanded. This suggests why Ackerman's theory might explain how constitutional politics authorized the New Deal Justices to hand down their transformative opinions, but it cannot

48. Patricia Sullivan, Days of Hope: Race and Democracy IN THE New DEAl ERA 191 (1996).

49. Broad social and economics rights-talk fell into disuse after the decisive defeats the New Deal agenda suffered in the 1940s. Blocked by the Dixiecrats at every legislative crossroad, the CIO, social citizenship's only powerful, organized constituency, gradually abandoned its efforts to complete the New Deal. By the mid-1950s the industrial unions had begun instead to fashion with employers a private system of social provision and job security through collective bargaining in core sectors of the economy. During the same moment, the rigid consensus politics of the Cold War eclipsed the confident liberalism of New Deal America. 
readily show how the "rights of citizens" were transformed by the New Deal moment. Matters would be different if the only fault line were the exclusion of blacks from a newly-enacted national commitment to social citizenship. But as we have seen, the betrayal of Reconstruction had more pervasive consequences. It subverted white America's capacity to enact even a racially exclusionary form of social citizenship. Accordingly, there is no "synthesis" of racial equality and social rights to be drawn here; the fault lines are too many.

Thus, Ackerman points to "the Full Employment Act" of 1946 as a "framework statute" that was "part of the New Deal Constitution" "We the People" had forged..$^{50}$ But as we have seen, "We" hollowed out the constitutional substance of that statute. What possible precommitment could one draw from the 1946 Act to constrain the "ordinary politics" of today? In general, the commitments "We" made to ourselves in the New Deal moment were too deeply compromised by past and present inconstancies to undergird the kind of "preservative" theory Ackerman desires.

That is the conclusion I draw from reknitting these few strands of Ackerman's narrative in the light of the historians' insights. This narrative suggests that even constitutional moments of popular deliberation and decision making may be concluded by force and fraud, or constrained by the institutional inheritances of prior moments that merit little legitimacy even by Ackerman's forgiving lights. History pursued in this fashion may yield an irremediable plurality of past constitutional choices and commitments, and we must choose which of them bind us. Or we may decide simply that we are bound to reopen those constitutive questions that were concluded illegitimately. Ackerman's narrative aims for more robust prescriptions: rules of recognition that entail no such substantive choices, that identify the authoritative texts and meanings from past moments. Even were that project finally plausible, it would assume a reader whose interpretive interests are all backward-looking and concerned with authoritative guidance and binding conclusions. Historians ironically may assume a more forwardlooking audience, at least insofar as the latter's tradition-interpreting interests are concerned. A lay public making present sense of past constitutional conflicts and commitments seeks insights that bear on the field of citizenly debate and action. So, historians prize more searching conversations with the past that offer less determinate and more choiceladen meanings for the present. That may be all that Ackerman can offer as well; he has imbued his theoretical narrative too deeply with historical learning and imagination to offer less. He has earned our gratitude and admiration.

50. 1 ACKERMAN, supra note 3, at $107 \mathrm{n}^{*}$. Ackerman gets the law's actual title wrong; it was the "Employment Act of 1946," reflecting the removal of the new federal right and the institutional and policy innovations proposed in the "Full Employment Act of 1945." 